\title{
The Analysis of De Minimis Aid Granted in Poland in Years 2008-2015
}

\author{
Bartosz BARTNICZAK \\ Wrocław University of Economics, Wrocław, Poland \\ Bartosz.bartniczak@ue.wroc.pl
}

\begin{abstract}
When state provides state aid it interferes in the market mechanism. Providing support without any restrictions could lead to adverse changes in the market. De minimis aid is a type of support that is allowed under European law. De minimis support is given in small amounts, which results in negligible impact on competition. Monitoring de minimis aid is very important issue. This will allow to show us the main directions of the support, as well as changes in the allocation of support in different years. The main aim of the article is to make analysis of de minimis aid granted in Poland in years 2008-2014. The analysis covers the structure of granted aid and also an analysis of dynamics.
\end{abstract}

Keywords: State Aid, Poland, De Minimis Aid.

\section{Introduction}

State aid is a term introduced by the European Commission and regulated in Art. 107 paragraph 1 TFEU [3]. To the measure could be regarded as state aid under this article must be met including four conditions: intervention by the state or through state resources, the intervention gives the recipient an advantage on a selective basis, competition has been or may be distorted and the intervention is likely to affect trade between Member States.

In the article was made the analysis of the de minimis aid granted in the years 2008-2015. This analysis was carried out in relation to the total value of the aid, dynamics analysis of granted state aid, the forms in which this support was given, methods of financing aid and its destination.

\section{Methods, literature overview}

Contemporary economic reality is so complicated that it is difficult to imagine the functioning of the market mechanism in isolation from the state. One of the instruments through which the state can intervene in a market economy is state aid. In Europe the provision of subsidies and other forms of aids by the State or through State resources still form an accepted part, indeed often a central part, of economic policy, 
even in those countries most attached to the model of the free market. [1] It shall be considered part of the economic state intervention, which aims to stimulate positive economic developments or prevention of negative processes [7]. The concept of state aid is wider than a subsidy because it embraces not only positive benefits, such as subsidies themselves, but also interventions which, in various form, mitigate the charges which are normally included in the budget of the undertaking and which, without therefore being subsidies in the strict sense of the word are similar in character and same the same effect [19]. This aid can be considered as a tool in the hands of public authorities, which is used to achieve different objectives and tasks of social and economic policy. Governments grants state aid for many reasons: economic, social, political and strategic [2]. Despite the widespread occurrence the phenomenon of state aid there is no legal (normalized by law) the definition of that term. State aid policy is still changing. Public authorities find new methods of supporting entrepreneurs. So we still need to assess and re-interpret state aid rules [8]. State aid could be understood as one of the remaining difficulties in creating an integrated single market [10].

Issues concerning the admissibility of state aid are governed by Art. 107-109 Treaty of Functioning European Union [5]. Article 107 paragraph. 1 indicates only that ,save as otherwise provided in the Treaties, any aid granted by a Member State or through state resources in any form whatsoever which distorts or threatens to distort competition by favouring certain undertakings or the production of certain goods shall, in so far as it affects trade between Member States, be incompatible with the internal market". Analysis of the provisions of this article allows to conclude that it would be prohibited to provide aid if the conditions referred to therein are together fulfilled. For these circumstances include the transfer of state resources, obtaining economic benefits, the selective nature and occurrence of the effect on competition and trade.

Despite its distortive effects on competition, it has to be acknowledged that some state aid when granted digressively and limited in time, can contribute to stimulating certain activities or ease structural changes in the economy [9]. De minimis aid because of the low unit value, not are a threat to competition disruption to the market European Union. Aid of this kind does not constitute state aid within the meaning of Article 107 Paragraph 1 TFEU . Matters relating to de minimis aid are governed by the Council Regulation on the application of Articles 107 and 108 of the Treaty to de minimis aid [4]. According to this regulation:

- the total value of the de minimis rule for a beneficiary cannot exceed 200 thousand euro in the period of three years,

- support the entrepreneur cannot get threatened by the guidelines on State aid for rescuing and restructuring firms in difficulty ,

- aid must be "transparent", ie it must be possible to calculate the ex ante gross grant equivalent without the need for risk assessment,

- in some sectors (agriculture, fisheries, aquaculture, transport and coal) to grant de minimis aid shall be subject to special rules, exclusionary or limiting the possibility of granting it. 
The research period covered the years 2008-2015. The data needed for the analysis come from the reports on de minimis aid granted in Poland in subsequent years, which were published annually by the Office of Competition and Consumer Protection. In the paper were used methods of statistical analysis and an analysis of the dynamics of the structure of the support.

\section{Results}

The value of de minimis aid increased very rapidly from 2008 to 2010 (Tab. 1). In 2009 , it was more than twice as high as the previous year (having increased by over $133 \%$ ), and in 2010 , it grew by $50 \%$ in comparison with 2009 . In 2011 , the value of de minimis aid fell by about $28 \%$ compared with the previous year, returning to a level comparable with 2009. 2012 saw a rise in the total value of de minimis aid by about $24 \%$ in comparison with 2011. The upward trend continued for the next two years. In 2013, the value of de minimis aid increased by more than $40 \%$ compared with 2012 , and in 2014 - by more than $11 \%$ compared with 2013 . In 2015 , much like in 2011 , the value of the aid provided decreased by about $28 \%$ in comparison with the previous year.

Table 1. Value of state aid and de minimis aid from 2008 to 2015 (in millions of euro) $[11,12,13,14,15,16,17,18]$.

\begin{tabular}{|c|c|c|c|c|c|c|c|c|}
\hline Specification & 2008 & 2009 & 2010 & 2011 & 2012 & 2013 & 2014 & 2015 \\
\hline $\begin{array}{l}\text { Value of state aid (in } M \\
\text { EUR) }\end{array}$ & 4090.1 & 4394.5 & 6030 & 5211.2 & 4873.9 & 4912.1 & 6036.2 & 4626.7 \\
\hline $\begin{array}{l}\text { Value of de minimis aid } \\
\text { (in M EUR) }\end{array}$ & 329.7 & 770.7 & 1156.2 & 836.6 & 1034.5 & 1463.5 & 1630.9 & 1169.5 \\
\hline
\end{tabular}

A comparison of the amounts of state aid provided in accordance with the requirements of Article 107 of the TFEU [5] and de minimis aid shows that the amount of the latter is considerably smaller, which is understandable considering the limitation of the amount of de minimis aid a single entrepreneur can receive.

In 2008, de minimis aid accounted for $8 \%$ of the total value of the aid provided to entrepreneurs. Between 2009 and 2011, it constituted, on average, just under 17\%. In the following years, its percentage exceeded 20\%, peaking at nearly 30\% in 2013 . This was a result of the considerable increase in the value of de minimis aid in 2013 and 2014 in comparison with 2012. It is worth noting that despite the decline in the total value of aid provided, the percentage of de minimis aid in 2015 remained at roughly the same level as in the two previous years. It was affected neither by the significant surge in state aid in 2014 nor by its sharp fall in 2015.

It is also worth noting that between 2008 and 2015, the trends (upward/downward) in state aid value and de minimis aid value were mostly concurrent. The only exception was 2012, when the value of state aid fell by just under $7 \%$ and de minimis aid increased by nearly $24 \%$ compared to the previous year. 
In 2009, the rate of change of the value of de minimis aid (an increase by more than $123 \%$ ) was higher than in the case of state aid (an increase by about $7 \%$ ). In 2010, the rates were similar (37\% increase in total aid, 50\% increase in de minimis aid). This was also the case in 2011 (a decrease by about $14 \%$ and $28 \%$ respectively). In 2013, the rise in the value of de minimis aid was significantly larger than in the case of state aid: $40 \%$ as opposed to less than $1 \%$. In 2014, the rate of change of the value of de minimis aid (an increase by about $11 \%$ ) was lower than in the case of state aid (an increase by almost $23 \%$ ). In 2015, in turn, the rates were similar (a decrease by about $26 \%$ ).

Table 2 presents data concerning forms of de minimis aid divided into four groups marked with the letters A, B, C and D. Subgroups were identified within each group and marked with the number 1 or 2 depending on whether they involve a payout of funds from the budget (1) or a reduction of budget contributions (2).

Table 2. Forms of de minimis aid between 2008 and 2015 (in millions of euro) $[11,12,13,14,15,16,17,18]$.

\begin{tabular}{lllllllll}
\hline Specification & $\mathbf{2 0 0 8}$ & $\mathbf{2 0 0 9}$ & $\mathbf{2 0 1 0}$ & $\mathbf{2 0 1 1}$ & $\mathbf{2 0 1 2}$ & $\mathbf{2 0 1 3}$ & $\mathbf{2 0 1 4}$ & $\mathbf{2 0 1 5}$ \\
\hline $\begin{array}{l}\text { A: grants and tax } \\
\text { exemptions }\end{array}$ & 303.4 & 741.5 & 1117.1 & 795.3 & 968.3 & 1138.8 & 1342.2 & 936.1 \\
A1: grants & 232 & 662.1 & 1038.5 & 704.2 & 911 & 1070.6 & 1268 & 863.2 \\
$\begin{array}{l}\text { A2: tax exemptions } \\
\text { B: state equity }\end{array}$ & 71.4 & 79.3 & 78.6 & 91.1 & 57.2 & 68.2 & 74.2 & 72.9 \\
participation & 0.3 & 0.2 & 5.3 & 4.4 & 12.1 & 24.6 & 17.4 & 41.7 \\
$\begin{array}{l}\text { B1: contribution of } \\
\text { capital }\end{array}$ & 0.3 & 0.2 & 5.3 & 4.4 & 12.1 & 24.6 & 17.4 & 41.7 \\
$\begin{array}{l}\text { C: soft loans } \\
\text { C1: participatory }\end{array}$ & 19.2 & 20.7 & 21.3 & 21.4 & 27.1 & 44.3 & 49.7 & 45.5 \\
loans & 10.9 & 9.5 & 9.8 & 12.5 & 11.6 & 24.7 & 28.5 & 30 \\
$\begin{array}{l}\text { C2: tax deferral or } \\
\text { division into }\end{array}$ & & & & & & & & \\
instalments & 8.3 & 11.2 & 11.5 & 8.9 & 15.6 & 19.6 & 21.2 & 15.4 \\
D1: guarantees & 0 & 0.1 & 1.6 & 5.7 & 10.5 & 235.7 & 189.6 & 110.7 \\
E: others & 6.8 & 8.3 & 10.9 & 9.7 & 16.5 & 20.1 & 32.1 & 35.4 \\
Total & 329.7 & 770.8 & 1156.2 & 836.5 & 1034.5 & 1463.5 & 1631 & 1169.4 \\
\hline
\end{tabular}

In terms of the size of the beneficiary, it can be noticed that in each of the years analysed, a majority of the aid was provided to micro-enterprises, which received more than $72 \%$ of the total aid (Tab. 3). The combined amount of aid provided to micro, small and medium-sized enterprises during the period analysed constituted $95 \%$ of the total. Reasons for this phenomenon may include the fact that de minimis aid is provided under simple rules, often with no connection to a particular project, as well as the fact that the capital absorption capabilities of such companies are limited. Most of the entities classified as large enterprises are communes. In 2015, seven of the ten beneficiaries classified as large enterprises that received the most aid were 
communes (local governments that engage in business activity are enterprises according to EU law), which received de minimis aid mainly pursuant to the Act of 7 March 2007 on support for the development of rural areas using resources of the European Agricultural Fund for Rural Development as part of the Rural Development Programme for 2007-2013 [24] and the Act on the principles of development policy [31].

Table 3. Structure of de minimis aid by size of the beneficiary between 2008 and $2015(\%)$ $[11,12,13,14,15,16,17,18]$.

\begin{tabular}{lllllllll}
\hline Size of the beneficiary & $\mathbf{2 0 0 8}$ & $\mathbf{2 0 0 9}$ & $\mathbf{2 0 1 0}$ & $\mathbf{2 0 1 1}$ & $\mathbf{2 0 1 2}$ & $\mathbf{2 0 1 3}$ & $\mathbf{2 0 1 4}$ & $\mathbf{2 0 1 5}$ \\
\hline micro & 63.2 & 77.4 & 76.9 & 77.3 & 77.3 & 69.0 & 70.3 & 65.5 \\
small & 15.5 & 11.5 & 11.2 & 9.5 & 11.1 & 16.7 & 17.5 & 19.5 \\
medium & 13.8 & 6.9 & 7.3 & 8.1 & 6.9 & 10.5 & 9 & 9.8 \\
large & 7.5 & 4.2 & 4.6 & 5.1 & 4.7 & 3.8 & 3.2 & 5.2 \\
Total & 100 & 100 & 100 & 100 & 100 & 100 & 100 & 100 \\
\hline
\end{tabular}

Data concerning the legal frame of business activity of the beneficiaries of de minimis aid is available for the years 2012-2015 (Tab. 4). In each of these years, a vast majority of the aid was provided to private entrepreneurs - on average, it constituted $96,1 \%$ of the total. The percentage of other beneficiaries was minimal.

Table 4. Structure of de minimis aid by legal frame of business activity of the beneficiary between 2012 and 2015 (\%) [11,12,13,14,15,16,17,18].

\begin{tabular}{|c|c|c|c|c|}
\hline Legal frame & 2012 & 2013 & 2014 & 2015 \\
\hline Private entrepreneurs & 95.3 & 96.5 & 96.4 & 94.68 \\
\hline $\begin{array}{l}\text { Joint-stock companies and limited liability companies for which } \\
\text { the State Treasury, a local government unit and a state or } \\
\text { communal organisational unit are dominant entities }\end{array}$ & 4.0 & 2.9 & 3.1 & 3.25 \\
\hline $\begin{array}{l}\text { Companies and partnerships in which a local government unit } \\
\text { holds } 100 \% \text { of the stocks or shares }\end{array}$ & 0.3 & 0.3 & 0.2 & 1.5 \\
\hline $\begin{array}{l}\text { Public finance entities as defined by the Act of } 27 \text { August } 2009 \\
\text { on public finance (Journal of Laws } 2013 \text {, item } 885 \text {, as amended) }\end{array}$ & 0.2 & 0.2 & 0.2 & 0.4 \\
\hline State enterprises & 0.2 & 0.1 & 0.1 & 0.13 \\
\hline Single-member companies of the State Treasury & 0.1 & 0.1 & 0 & 0.04 \\
\hline Total & 100.1 & 100.1 & 100 & 100 \\
\hline
\end{tabular}

Table 5 presents the amount of aid by voivodship. The criterion for the determination of the amount of aid provided to individual voivodeships was the location of the registered office of the enterprise that received the aid. As a result, the high value of de minimis aid assigned to some voivodeships may stem from the fact that many entrepreneurs choose to establish their head offices in large cities. There is, however, a possibility of an enterprise whose registered office is located in one voivodeship 
receiving de minimis aid in connection with business activity conducted in another voivodeship (e.g. maintaining a branch there) [18]. In each of the years analysed except 2011, the largest amount of aid was provided to enterprises operating in Mazovian Voivodeship. In 2011, entrepreneurs from Greater Poland Voivodeship received the most aid. In the remaining years, Greater Poland was either second or third, alternating with Silesian Voivodeship.

Table 5. Share of individual voivodeships in the total amount of de minimis aid provided from 2008 to $2015(\%)[11,12,13,14,15,16,17,18]$.

\begin{tabular}{lllllllll}
\hline Voivodeships & $\mathbf{2 0 0 8}$ & $\mathbf{2 0 0 9}$ & $\mathbf{2 0 1 0}$ & $\mathbf{2 0 1 1}$ & $\mathbf{2 0 1 2}$ & $\mathbf{2 0 1 3}$ & $\mathbf{2 0 1 4}$ & $\mathbf{2 0 1 5}$ \\
\hline Wielkopolskie & 10.8 & 8.6 & 11.8 & 13.7 & 11.4 & 11.8 & 10.2 & 10.9 \\
Kujawsko-Pomorskie & 4.9 & 6.8 & 6.1 & 6.7 & 5.6 & 5.1 & 5.7 & 6.2 \\
Małopolskie & 7.2 & 8.4 & 8.4 & 9.4 & 9.2 & 7.7 & 8.9 & 8.2 \\
Dolnośląskie & 8.8 & 6.4 & 6.4 & 6.1 & 6.6 & 6.8 & 6.8 & 7.5 \\
Lubelskie & 4.2 & 5.3 & 5.3 & 5.8 & 6.3 & 5.3 & 5.5 & 4.4 \\
Lubuskie & 3.1 & 2.6 & 2.7 & 2.4 & 2.5 & 2.3 & 2.6 & 2.6 \\
Łódzkie & 7.9 & 6.3 & 6.9 & 6.2 & 6.4 & 6 & 6.1 & 5.8 \\
Mazowieckie & 11.4 & 13.7 & 12.2 & 12.4 & 13.6 & 16.6 & 14.5 & 15.0 \\
Opolskie & 2.9 & 3.3 & 4 & 2.2 & 2.7 & 2.3 & 2.3 & 2.7 \\
Podlaskie & 2.4 & 2.5 & 2.9 & 3.4 & 3.6 & 2.6 & 3 & 2.7 \\
Pomorskie & 7.6 & 7.3 & 5.8 & 5.5 & 5.3 & 6 & 5.9 & 6.5 \\
Śląskie & 10.2 & 9.7 & 9.6 & 7.6 & 8.1 & 9.6 & 9.9 & 10.2 \\
Podkarpackie & 5.4 & 6.9 & 7 & 6.4 & 6.4 & 6.2 & 7.2 & 5.8 \\
Świętokrzyskie & 4.2 & 4.1 & 3.6 & 4.2 & 3.4 & 3 & 3.1 & 3.1 \\
Warmińsko-Mazurskie & 4.9 & 4.4 & 4 & 4.2 & 4.8 & 4.3 & 3.9 & 4.3 \\
Zachodniopomorskie & 4 & 3.7 & 3.5 & 3.8 & 4.3 & 4.5 & 4.4 & 4.3 \\
Total & 100 & 100 & 100 & 100 & 100 & 100 & 100 & 100 \\
\hline
\end{tabular}

The variation in the amounts of aid provided to enterprises in individual voivodeships may stem from the fact that voivodeships differ significantly in terms of their level of entrepreneurship understood as the percentage of entrepreneurs operating in a given voivodeship in the total number of entrepreneurs registered in Poland. This means that conducting analyses based solely on the total values of aid provided in each voivodeship may be misleading. Levels of entrepreneurship in each voivodeship are therefore presented in Table 6.

The level of entrepreneurship was higher than the voivodeship's share in the total aid provided in Poland in 6 voivodeships in 2009, 7 in 2010 and 2011, 6 in 2012 and 8 in 2014 and 2015. In the remaining voivodeships, the level of entrepreneurship was lower than the percentage of the aid provided to a given voivodeship. In each of the years analysed - except 2013 - the largest difference between the level of 
entrepreneurship and the share in the total state aid provided in Poland could be observed in Mazovian Voivodeship.

Table 6. Level of entrepreneurship in Polish voivodeships between 2009 and 2015 (\%) $[11,12,13,14,15,16,17,18]$.

\begin{tabular}{lllllllll}
\hline Voivodeship & $\mathbf{2 0 0 8}$ & $\mathbf{2 0 0 9}$ & $\mathbf{2 0 1 0}$ & $\mathbf{2 0 1 1}$ & $\mathbf{2 0 1 2}$ & $\mathbf{2 0 1 3}$ & $\mathbf{2 0 1 4}$ & $\mathbf{2 0 1 5}$ \\
\hline Wielkopolskie & - & 9.6 & 9.6 & 9.7 & 9.8 & 9.8 & 9.8 & 9.9 \\
Kujawsko-Pomorskie & - & 4.9 & 4.8 & 4.8 & 4.7 & 4.7 & 4.7 & 4.7 \\
Małopolskie & - & 8.4 & 8.5 & 8.6 & 8.6 & 8.6 & 8.7 & 8.7 \\
Dolnośląskie & - & 8.5 & 8.5 & 8.5 & 8.5 & 8.5 & 8.5 & 8.5 \\
Lubelskie & - & 4.2 & 4.2 & 4.2 & 4.2 & 4.2 & 4.2 & 4.1 \\
Lubuskie & - & 2.7 & 2.7 & 2.7 & 2.7 & 2.5 & 2.7 & 2.7 \\
Lódzkie & - & 5.9 & 5.9 & 5.9 & 5.9 & 5.8 & 5.8 & 5.8 \\
Mazowieckie & - & 17.3 & 17.4 & 17.4 & 17.6 & 17.8 & 18 & 18.4 \\
Opolskie & - & 2.6 & 2.5 & 2.5 & 2.5 & 2.7 & 2.4 & 2.4 \\
Podlaskie & - & 2.4 & 2.4 & 2.4 & 2.4 & 2.4 & 2.4 & 2.4 \\
Pomorskie & - & 6.7 & 6.7 & 6.7 & 6.7 & 6.7 & 6.7 & 6.6 \\
Śląskie & - & 11.5 & 11.6 & 11.5 & 11.4 & 11.3 & 11.2 & 11.2 \\
Podkarpackie & - & 3.9 & 3.9 & 3.9 & 3.9 & 3.9 & 3.9 & 4.0 \\
Świętokrzyskie & - & 2.82 & 2.8 & 2.7 & 2.7 & 2.7 & 2.7 & 2.6 \\
Warmińsko-Mazurskie & - & 3.1 & 3.0 & 3.0 & 3 & 3 & 3 & 2.9 \\
Zachodniopomorskie & - & 5.8 & 5.6 & 5.5 & 5.5 & 5.4 & 5.3 & 5.2 \\
Total & - & 100 & 100 & 100 & 100 & 100 & 100 & 100 \\
\hline & & & & & & & &
\end{tabular}

Table 7 presents information regarding the value of de minimis aid by legal basis for its provision. From 2008 to 2010 and from 2013 to 2015, the most aid was provided pursuant to the Act on employment promotion and labour market institutions [23]. Pursuant to the Act, aid is provided by Voluntary Labour Corps in the form of reimbursement of the remuneration of adolescent workers and by starostes as part of intervention works. From 2011 to 2012, most of the aid was provided pursuant to the Act on support for the development of rural areas using resources of the European Agricultural Fund for Rural Development as part of the Rural Development Programme for 2007-2013 [24]. Analysing the presented data, one can conclude that the value and the changes in the value of aid provided pursuant to a given legislative act were principally determined by the redistribution of funds originating from the budget of the European Union. 
Table 7. Value of de minimis aid by legal basis for its provision from 2008 to 2015 (\%) $[11,12,13,14,15,16,17,18]$.

\begin{tabular}{|c|c|c|c|c|c|c|c|c|}
\hline Act & 2008 & 2009 & 2010 & 2011 & 2012 & 2013 & 2014 & 2015 \\
\hline $\begin{array}{lr}\text { on } & \text { employment } \\
\text { promotion } & \text { and labour } \\
\text { market } & \text { institutions } \\
{[23]} & \end{array}$ & 596.9 & 1452.2 & 2121 & 613.8 & 1100 & 1319.6 & 1787.5 & 2252.7 \\
\hline $\begin{array}{l}\text { on the principles of } \\
\text { development policy } \\
{[31]}\end{array}$ & 11.1 & 364.5 & 728 & 603.9 & 734.1 & 1198.5 & 1398.6 & 618.9 \\
\hline $\begin{array}{l}\text { on guarantees issued } \\
\text { by the state treasury } \\
\text { and some legal entities } \\
\text { [21] }\end{array}$ & - & - & & - & - & 932.6 & 745.7 & 421.6 \\
\hline $\begin{array}{l}\text { on the creation of the } \\
\text { Polish Agency for } \\
\text { Enterprise } \\
\text { Development [33] }\end{array}$ & 3.2 & 451.9 & 576.9 & 307.2 & 406.4 & 1027.9 & 936.5 & 397 \\
\hline $\begin{array}{l}\text { Environmental } \\
\text { Protection Law [26] }\end{array}$ & 65.9 & 97 & 121.6 & 132.1 & 156.7 & 188.6 & 201.9 & 272 \\
\hline $\begin{array}{l}\text { on the system of } \\
\text { education [32] }\end{array}$ & - & - & - & - & 191 & 224.5 & 184.4 & 212.2 \\
\hline $\begin{array}{l}\text { on support for the } \\
\text { development of rural } \\
\text { areas using resources } \\
\text { of the European } \\
\text { Agricultural Fund for } \\
\text { Rural Development as } \\
\text { part of the Rural } \\
\text { Development } \\
\text { Programme for 2007- } \\
2013 \text { [24] }\end{array}$ & - & 325.5 & 448.3 & 1165.5 & 1228.2 & 708.4 & 963.8 & 163.4 \\
\hline $\begin{array}{l}\text { on vocational and } \\
\text { social rehabilitation } \\
\text { and employment of } \\
\text { persons with } \\
\text { disabilities [27] }\end{array}$ & 99.3 & 191.9 & 196.8 & 196.4 & 176.1 & 143.1 & 154.9 & 147.8 \\
\hline $\begin{array}{l}\text { Tax Ordinance Act } \\
{[29]}\end{array}$ & 65.5 & 75.4 & 71.2 & 73.3 & 73 & 84.2 & 95.1 & 87.8 \\
\hline $\begin{array}{l}\text { on local taxes and } \\
\text { charges [20] }\end{array}$ & 78.4 & 90.5 & 104.4 & 102.5 & 63.4 & 70.7 & 80.4 & 81.7 \\
\hline $\begin{array}{l}\text { on personal income } \\
\text { tax [25] }\end{array}$ & 96.3 & 105.8 & 121.4 & 183.9 & 91.4 & 83.4 & 83.1 & 74.9 \\
\hline $\begin{array}{l}\text { on the National Centre } \\
\text { for Research and } \\
\text { Development [30] }\end{array}$ & - & - & - & - & - & - & & 23.1 \\
\hline $\begin{array}{l}\text { on the conversion of } \\
\text { the right of perpetual } \\
\text { usufruct into an } \\
\text { ownership title to real } \\
\text { estate [28] }\end{array}$ & - & - & - & - & - & - & 62.2 & 22.5 \\
\hline $\begin{array}{l}\text { on the National } \\
\text { Development Plan } \\
{[30]}\end{array}$ & 47.7 & - & - & - & - & - & - & - \\
\hline other legislative acts & 95.1 & 129.0 & - & 68.0 & 109.2 & 161.5 & 131.3 & 117.2 \\
\hline Total & 1159.4 & 3283.7 & 4489.6 & 3446.6 & 4329.5 & 6143 & 6825.4 & 4892.8 \\
\hline
\end{tabular}




\section{Discussion}

The conducted analysis show that in Poland in years 2008-2015 nearly 8,4 bln euro of de minimis aid were granted. The main form of granted aid were grants. A majority of the aid was provided to micro-enterprises, which received more than $72 \%$ of total aid. A vast majority of the aid was provided to private entrepreneurs $-96,1 \%$ of the total aid. Reasons for this phenomenon may include the fact that de minimis aid is provided under simple rules, often with no connection to a particular project.

\section{Conclusion}

Current economic reality is so complicated that it is difficult to imagine the functioning of the market mechanism without state intervention. This intervention, however, can lead to significant distortions in the market. Therefore so important is to monitor of granted state aid.

It should be emphasized that the state also operates imperfectly, with the result that its intervention should be limited only to those cases where it can be an effective tool for solving specific problems. This makes it necessary to restrict and monitor granted state aid.

\section{References}

1. Biondi A., Eeckhot P., Flynn J.: The law of state aid in the European Union. Oxford Univeristy Press, New York 2003.

2. Hancher, L., Ottervanger, T., Slot P. J.: EU State aids. 4th edn. Sweet\&Maxwell, London (2012).

3. European Commission (2012). Consolidated version of the Treaty on the Functioning of the European Union, O.J. C 326/2012.

4. European Commission (2013). Commission Regulation (EU) No 1407/2013 of 18 December 2013 on the application of Articles 107 and 108 of the Treaty on the Functioning of the European Union to de minimis aid, OJ L 352/1.

5. European Commission (2012). Consolidated version of the Treaty on the functioning of the European Union. OJ C326/47.

6. European Economic and Social Committee and the Committee of the Regions (2012). Communication from the Commission to the European Parliament. EU State Aid Modernisation (SAM), COM (2012) 209 final.

7. Modzelewska-Wąchal, E., Pełka P., Stasiak M.: Pomoc publiczna dla przedsiębiorców i jej nadzorowanie. Przepisy i komentarze. LexisNexis, Warszawa (2001).

8. Nicolaides, P., Kekelekis, M., Buyskes P.: State aid policy in the European Community. A guide for practitioners. Kluwer Law International, Hague (2005).

9. Sanchez Rydelski M.: The EC State Aid Regime: Distortive effects on state aid on competition and trade. Cambridhe Univeristy Press, London 2006.

10. Szyszczak, E.: Research handbook on European state aid law. Edward Elgar, Cheltenham (2011). 
11. Urząd Ochrony Konkurencji i Konsumentów: Pomoc de minimis w Polsce udzielona przedsiębiorcom w 2008, https://uokik.gov.pl/raporty_i_analizy2.php, last accessed 2017/08/10

12. Urząd Ochrony Konkurencji i Konsumentów: Pomoc de minimis w Polsce udzielona przedsiębiorcom w 2009, https://uokik.gov.pl/raporty_i_analizy2.php, last accessed 2017/08/10

13. Urząd Ochrony Konkurencji i Konsumentów: Pomoc de minimis w Polsce udzielona przedsiębiorcom w 2010, https://uokik.gov.pl/raporty_i_analizy2.php, last accessed 2017/08/10.

14. Urząd Ochrony Konkurencji i Konsumentów: Pomoc de minimis w Polsce udzielona przedsiębiorcom w 2011, https://uokik.gov.pl/raporty_i_analizy2.php, last accessed 2017/08/10.

15. Urząd Ochrony Konkurencji i Konsumentów: Pomoc de minimis w Polsce udzielona przedsiębiorcom w 2012, https://uokik.gov.pl/raporty_i_analizy2.php, last accessed 2017/08/10.

16. Urząd Ochrony Konkurencji i Konsumentów: Pomoc de minimis w Polsce udzielona przedsiębiorcom w 2013, https://uokik.gov.pl/raporty_i_analizy2.php, last accessed 2017/08/10.

17. Urząd Ochrony Konkurencji i Konsumentów: Pomoc de minimis w Polsce udzielona przedsiębiorcom w 2014, https://uokik.gov.pl/raporty_i_analizy2.php, last accessed 2017/08/10.

18. Urząd Ochrony Konkurencji i Konsumentów: Pomoc de minimis w Polsce udzielona przedsiębiorcom w 2015, https://uokik.gov.pl/raporty_i_analizy2.php, last accessed 2017/08/10.

19. Wishlade, F.: Regional state aid and Competition Policy in the European Union. Kluwer Law International, Hague (2003).

20. Ustawa z dnia 12 stycznia 1991 r. o podatkach i opłatach lokalnych, Dz. U. z 1991 r., nr 9, poz. 31 .

21. Ustawa $z$ dnia 2 kwietnia 2009 r. o zmianie ustawy o poręczeniach i gwarancjach udzielanych przez Skarb Państwa oraz niektóre osoby prawne, ustawy o Banku Gospodarstwa Krajowego oraz niektórych innych ustaw, Dz. U. z 2009 r., nr 66, poz. 545.

22. Ustawa z dnia 20 kwietnia 2004 r. o Narodowym Planie Rozwoju, Dz. U. z 2004 r., nr 116, poz. 1206 .

23. Ustawa z dnia 20 kwietnia 2004 r. o promocji zatrudnienia i instytucjach rynku pracy, Dz. U. z 2004 r., nr 99, poz. 1001.

24. Ustawa z dnia 7 marca 2007 r. o wspieraniu rozwoju obszarów wiejskich z udziałem środków Europejskiego Funduszu Rolnego na rzecz Rozwoju Obszarów Wiejskich w ramach Programu Rozwoju Obszarów Wiejskich na lata 2007-2013, Dz. U. z 2007 r., nr 64, poz. 427.

25. Ustawa z dnia 26 lipca 1991 r. o podatku dochodowym od osób fizycznych, Dz. U. z 1991 r., $\mathrm{nr} 80$, poz. 350 .

26. Ustawa z dnia 27 kwietnia 2001 r. Prawo ochrony środowiska, Dz. U. z 2001 r., nr 62, poz. 627.

27. Ustawa z dnia 27 sierpnia 1997 r. o rehabilitacji zawodowej i społecznej oraz zatrudnianiu osób niepełnosprawnych, Dz. U. z 1997 r., nr 123, poz. 776.

28. Ustawa $z$ dnia 29 lipca 2005 r. o przekształceniu prawa użytkowania wieczystego w prawo własności nieruchomości, Dz. U. z 2005 r., nr 175, poz. 1459.

29. Ustawa z dnia 29 sierpnia 1997 r. - Ordynacja podatkowa, Dz. U. z 1997 r., nr 137, poz. 926. 
30. Ustawa z dnia 30 kwietnia 2010 r. o Narodowym Centrum Badań i Rozwoju, Dz. U. z 2010 r., nr 96, poz. 616.

31. Ustawa z dnia 6 grudnia 2006 r. o zasadach prowadzenia polityki rozwoju, Dz. U. z 2006 r., $\mathrm{nr} 227$, poz. 1658 .

32. Ustawa z dnia 7 września 1991 r. o systemie oświaty, Dz. U. z 1991 r., nr 95, poz. 425.

33. Ustawa $\mathrm{z}$ dnia 9 listopada 2000 r. o utworzeniu Polskiej Agencji Rozwoju Przedsiębiorczości, Dz. U. z 2000 r., nr 109, poz. 1158. 